GLOBAL JOURNAL OF PURE AND APPLIED SCIENCES VOL. 24, 2018: 181-189

COPYRIGHTC BACHUDO SCIENCE CO. LTD PRINTED IN NIGERIA ISSN 1118-0579 www.globaljournalseries.com, Email: info@globaljournalseries.com

\title{
ACCESSING GOOD QUALITY WATER IN HAZARDOUS MINING ENVIRONMENTS: COPING MECHANISMS FOR YOUNG WOMEN IN SELECTED DISTRICTS OF MASHONALAND CENTRAL, ZIMBABWE.
}

\author{
DAVID MAKWERERE, GILLIAN TAFADZWA CHINZETE AND CHARLES MASSIMO
}

(Received 24 July 2018; Revision Accepted 12 September 2018)

\begin{abstract}
The study focused on how environmental degradation due to unregulated illegal mining activities is affecting the welfare of communities in general and women in particular with regards to access good quality water. The methodological design was a qualitative approach and focused on the two districts of Shamva and Bindura in Mashonaland Central Province, Zimbabwe. The study noted that the area of environmental policing has remained weak and compromised owing to a combination of factors, key among them being the difficult socio-economic environment which has often seen a lot of communities destroying the environment around them, political populism leading to the destruction of local ecologies and general disregard of responsibilities by companies operating mining, construction, and other enterprises. This has seen the gradual destruction and pollution of fresh water bodies across the communities. The study revealed that there is a considerable level of pollution on some water bodies in the two districts. The pollution is largely caused by the use of mercury and cyanide by the illegal gold panners and artisanal miners in the area. This has restricted opportunities for women's access to safe domestic water. Women are using strategies such as outsourcing from neighboring communities with relatively safe water for domestic use, differentiating water for cooking and drinking and for other activities like bathing and laundry, water harvesting during rain seasons and buying from shops in extreme circumstances. In conclusion, the coping mechanisms only offer temporary relief and are not be sustainable in the long run.
\end{abstract}

KEY WORDS: Hazards, Coping Mechanisms, Mining, Environment, Legislation, Kyoto Protocol, Human Right

\section{INTRODUCTION}

Zimbabwe, just like most other developing countries in the global south, is faced with many developmental challenges. Higher prevalence of poverty in the country has put a strain on the country's natural environment. The economic collapse in Zimbabwe started in the late 1990s and reached its peak around 2008 when the country eventually adopted the multi-currency regime to replace the weakened Zimbabwean dollar. During this period, people engaged in many coping strategies in order to survive. One of the escape routes was the exploitation of natural resources including minerals. In Mashonaland Central Province, one of the popular activities is illegal gold mining. The illegal mining activities have seen increased pollution and contamination of water bodies. Whilst the economic effects of illegal gold mining are well-documented (Mujere and Isidro 2016), the focus on women has not been as largely documented. In this study, the focus was on how women access water in hazardous mining environments.
Water is regarded as a basic human entitlement. It is a precious resource that gives and sustains livelihoods for both human beings as well as the environment. However, the activities of individual entrepreneurs and cooperates have left this precious resource under serious threat as most of the water bodies are heavily contaminated and the availability of fresh water for domestic use scarce. The deterioration of the quality of water across Africa in general and Zimbabwe in particular is to a large extent a result of poor policing environment as well as failing economies (Environmental Management Agency 2015, Mlambo 2013, Mapira 2011).

The gradual economic collapse in Zimbabwe has had many negative effects across many spheres in the country. Whilst the economic and social effects of the economic collapse have been largely documented United Nations Development Programme 2010), it is still important to continue with the discussion albeit with a focus on women coping mechanisms in hazardous mining environments. As the economic fortunes of the country continued to deteriorate, citizens are forced to

David Makwerere, Department of Peace and Governance at Bindura University of Science Education.

Gillian Tafadzwa Chinzete, Department of Peace and Governance at Bindura University of Science Education.

Charles Massimo, Department of Peace and Governance at Bindura University of Science Education. 
find alternative survival means (Dreschler 2001). One area of alternative survival was the area of artisanal mining otherwise commonly known as panning in Zimbabwe.

Zimbabwe is a nation with vast mineral resources. Transparency International Zimbabwe (2012:6) underscored the paradoxical nature of the realities obtaining on the ground as it noted that:

"One of the greatest paradoxes of our time is how a nation so endowed with vast natural resources has some of the poorest citizens in the world. It also remains an enigma how a government that sits on the largest deposits of alluvial diamonds in the world, constituting $20-25 \%$ of the world's deposits and the second largest platinum deposits in the world, continues to struggle with adequately resourcing its national fiscus to finance all aspects of government expenditure."

It is a fact that mineral resources governance in Zimbabwe leaves a lot to be desired. There are a lot of leakages of the precious minerals, informal trading and above all a seemingly weak policing environment leading to a lot of undesirable consequences. Studies have focused on the challenges associated with natural resources governance, corruption and many other variables. This study had an interest on the gendered dimensions of the effects of mining activities on women in Zimbabwe as well as tracing the coping mechanisms employed by women in their daily lives.

\section{Conceptualizing Mining in Zimbabwe}

Mining in Zimbabwe comprises both formal and informal activities. Informal mining activities are largely popular with gold and diamond in the various areas in Zimbabwe. Gold panning is however the most prevalent because of the abundant deposits across districts and provinces in Zimbabwe. Gold panning has been referred to as artisanal mining of late as the government tries to find ways of regularizing the activities of the illegal miners. These illegal miners have popularly been referred to as Makorokoza (illegal miners) in many parts of Zimbabwe. However, in other parts they are also referred as Magwejalikein some parts of Manicaland where the pseudonym was originally meant to refer to illegal diamond miners at the pick of the diamond rush in Chiadzwa but have now been generalized to refer to anyone in the informal mining sector. In some parts of Mashonaland Central Province, especially in Bindura, Shamva and Mazowe Districts, the panners are also commonly referred to as MaGerman. Prasteyo, et al. (2010) view these informal mining activities as harmful to the environment and as illegal in most cases. Artisanal mining is usually a result of economic vulnerabilities in failing economies. As noted by Aryee, et al. (2003), artisanal mining is an activity for the poor and vulnerable as they try to irk out a living and are usually without any opportunities for formal employment.

Table 1: Human Security and Environmental Security in Zimbabwe

\begin{tabular}{|c|c|c|}
\hline & National Security Paradigm & Human Security Paradigm \\
\hline Goal & $\begin{array}{l}\text { Securing territorial, economic, } \\
\text { and political interests of the } \\
\text { nation, such as access to oil or } \\
\text { other resources or promoting } \\
\text { ideologies such as free-market } \\
\text { capitalism }\end{array}$ & $\begin{array}{l}\text { Protecting the wellbeing of } \\
\text { individuals and communities so } \\
\text { that they can live free from } \\
\text { fear, free from want, and free } \\
\text { to live in dignity }\end{array}$ \\
\hline Actors & Primarily military & $\begin{array}{l}\text { Multitrack efforts at top, mid-, } \\
\text { and community levels, } \\
\text { including government, civil } \\
\text { society, business, academic, } \\
\text { religious, media, and other } \\
\text { actors }\end{array}$ \\
\hline Analysis & $\begin{array}{l}\text { Threat assessments primarily } \\
\text { focus on terrorism, rogue } \\
\text { states, and weapons of mass } \\
\text { destruction }\end{array}$ & $\begin{array}{l}\text { Threat assessments include } \\
\text { weapons of mass destruction, } \\
\text { terrorism from state and non- } \\
\text { state actors, poverty, economic } \\
\text { disparity, discrimination } \\
\text { between groups, deadly } \\
\text { diseases, nuclear and } \\
\text { biological materials, and } \\
\text { environmental destruction and } \\
\text { climate change }\end{array}$ \\
\hline Budget & $\begin{array}{l}\text { Security budget geared toward } \\
\text { offensive military capacity }\end{array}$ & \begin{tabular}{lr}
\multicolumn{3}{l}{ Security budget requires robust } \\
investments in \\
efforts involving \\
development, \\
governance, and \\
diplomacy
\end{tabular} \\
\hline Global Ties & $\begin{array}{l}\text { National security seen as } \\
\text { relatively isolated from global } \\
\text { security }\end{array}$ & $\begin{array}{l}\text { Human security seen as } \\
\text { interdependent across state } \\
\text { lines }\end{array}$ \\
\hline
\end{tabular}


Adapted from Schirch, L. (2013:17)

Human security takes a paradigm departure from the more popular state security paradigm. Whilst the two concepts should ideally complement each other, lines can still be drawn on the differences between the two. Security is intrinsic to personal and state safety, access to government services and participation in political processes. In this discussion, the meaning of security is guided the UNDP'S (1994) Human Development Report. The UNDP's (1994) Human Development Report's definition of human security argues that the scope of global security should be expanded to include threats in seven areas namely; economic, political, food, health, community, personal and environmental security. Although the concept of human security emerged as a challenge to the traditional concept of security; it does not mean that the concepts are mutually exclusive. One cannot attain one without the other.

Human security is people-centered. Its focus shifts to protecting individuals. The important dimensions consist of the well-being of individuals and respond to ordinary people's needs in dealing with sources of threats. The concept of human security recognizes the notion that the provision of security goes beyond the government and includes other non-state actors such as civil society organizations and community members. The conceptualisation embraces the security of people from both violent and non-violent threats to lives and/or wellbeing and that such security or peace is dependent on sustainable development.

\section{The RegulatoryPolicy Environment}

The policy framework on mining and the environment in Zimbabwe continues to evolve. The major piece of legislation that is currently applicable is the Mines and Minerals Act(21:05). The Act is jointly applicable to the operations of various government ministries including the Ministry of Mines, Ministry of Environment and Tourism especially to its management agency, Environmental Management Authority (EMA) and although indirectly to the Ministry of Public Works also. Some salient provisions of this Act are listed below:

- $\quad$ Acquisition of a prospector'slicense;

- $\quad$ Appointment of an approved prospector who will perform the statutory pegging and registration of the area sought after;

- $\quad$ Notification of government agencies of the area concerned;

- A sitting or works plan for approval by the Ministry of Mines and;

- A comprehensive environmental impact assessment (EIA) of the proposed mining project.

Whilst the Act has a lot of other provisions relating to mining in Zimbabwe, the study had a specific interest on the provisions provided for above. Whilst the large-scale miners are compelled to fulfill the provisions of the act, the case is not always the same with the artisanal miners most of whom operate illegally and without following any procedure. Of the five critical procedures listed above, the last two have a serious implication on the integrity of the environment and the communities around. The need to protect and preserve the environment by providing a working plan as well as an environmental impact assessment is of paramount importance in any proposed mining activity. There are other complementary pieces of legislation relating to mining in Zimbabwe. This study took an interest on the Mining Regulations of 1990 which places greater emphasis on management and safety issues with a special focus on small-scale mining in Zimbabwe. The 1991 Mining Regulations placed greater emphasis on the mining of alluvial gold in Zimbabwe.

\section{Trends in Mining in Zimbabwe}

The mining sector in Zimbabwe is afflicted with many negative practices. This is in spite of its immense potential to contribute to the growth of the economy in the country. These negative practices are explained differently by different scholars. A study by Transparency International in Zimbabwe on corruption in the mining sector in Zimbabwe noted that part of the irresponsible mining practices in the mining sector in Zimbabwe are a result of corruption. Transparency International Zimbabwe (2012:44) noted that "illicit and corrupt dealings in the mining sector are largely rampant at the level of artisanal mining in Zimbabwe."

The mining sector is hamstrung with the reckless mining practices. Mlambo (2013:3) observed that "Zimbabwe's river systems and dams are heavily polluted to the extent that they are now endangering both aquatic and human life." The practice is widespread and the Environmental Management Agency (EMA 2015) attributes this to poor waste management. However, mining plays a bigger role in the destruction of the environment. Nyamukondiwa (2017) noted that"gold stamping mills formed the epicenter of mercury pollution, which is said to spread within a five-kilometer radius and thus contaminating the environment, humans and animals."

What is perhaps worrisome is the fact that the use of mercury is largely unregulated and unaccounted for especially within the informal mining sector. Nyamukondiwa (2017) found out that an estimated 50 tonnes of mercury are reportedly used every year by small-scale artisanal miners and mining companies in Zimbabwe and a further 150 is brought illegally by small scale miners." This trend poses serious health threats to the people around these communities as quite often the water and the environment are polluted. Mlambo (2013) observed that "cyanide and mercury are associated with a number of health effects such as kidney and brain damage, skin rushes, gene damage and failure of the central nervous system among other detrimental health failures."

\section{Women, Mining and the Environment}

It is important to apply a gender lenses when assessing mining activities and their impact on the environment. It is no doubt that the environmental effects of mining activities, pollution or otherwise, take a gendered dimension in many ways. Oxfam Australia (2009:7) observed that; "the impacts of mining operations are not gender neutral. Women can experience the direct and indirect consequences of mining operations in different, and often more pronounced, ways than men." This observation is important and was a central theme in this study as the study sought to explore the coping 
mechanisms among women affected by hazardous mining activities.

A particularly important observation by Oxfam Australia (2007:7) was that, "The effects of environmental damage and degradation can undermine women's capacity to provide food and clean water for their families, and subsequently lead to an increase in their workload such as having to walk greater distances to access water, fuel/wood, forest products and land to plant food crops."

\section{Environmental Effects}

There are many effects that are associated with unregulated mining activities. Illegal mining activities in the country rank among the top sources of environmental pollution and degradation in Zimbabwe. This is to a great extent attributable to the unethical and largely unregulated (albeit the existence of a splendid legal and institutional framework in Zimbabwe) mining activities of the artisanal miners. Illegal gold panning as well as the popular (among artisanal miners) and yet illegal gold refining processes involving cyanide rank among the top causes of environmental and especially water pollution in Zimbabwe. The high levels of corruption in almost all the sectors of the Zimbabwean economy have seen an upsurge in illegal mining activities and as a result the effects on the environment have continued unabated.

Shoko (2005) provides a more technical explanation of some of the environmental effects of illegal mining activities when he found out that unethical mining activities cause air pollution which then has an effect on radiation activities leading to a depletion on the ozone layer and eventually global warming. Mining by nature (especially gold-mining) is both labour intensive and water-intensive and if left unchecked can cause untold pollution to both the environment and the communities in which the mining is taking place. A lot of water is required to process the gold until it can be ready for marketing. Dreschler (2001) found that unregulated mining usually results in squatter camps along water bodies and thus adding to the pollution of the water bodies. Shoko (2005) noted that artisanal gold mining, most of which is illegal and unregulated in Zimbabwe, is a threat to safe water bodies.

Both the artisanal miners and the mining companies in Zimbabwe employ practices that threaten the environment in many ways. The use of mercury and cyanide remains popular among the informal miners. Some big mining companies have also been accused of using the chemicals to aid the purification process. However, environmental health specialists point out that the use of these chemicals have serious negative consequences on the environment in general and on water bodies in particular (Mlambo 2011). In Zimbabwe artisanal miners are mostly unaware of the health effects of these chemicals. In cases where they are aware of the effects, they are just ignorant or sometimes hardpressed to irk out a living to the extent that they find it irresistible to use the chemicals.

The situation is even made worse by corruption as the chemicals are easily accessible on the black market in Zimbabwe. Some artisanal miners indicated that in Bindura the chemicals can be acquired easily for as long as one was willing to pay cash. Dreschler (2001) and
Shoko (2005) observed that mercury and cyanide are the most commonly used chemicals whose effects will last for a very long time. An earlier study in Uganda by Mpendazoe (1996:110) established that the water in and around Lake Victoria Goldfields contained mercury in concentrations above the drinking water standard. Donkor (2006:3) found out that mercury is poisonous to both humans and aquatic based food chains. The use of mercury and cyanide in Zimbabwe is increasingly becoming a difficult challenge to handle. Cyanide is used by mining companies, illegal miners and of late poachers after elephants and rhinos in the country's major national game parks. According to Brown et al. (2012) surface water is the major source of water in Zimbabwe accounting for almost $90 \%$ of supply and use. If the use of cyanide and mercury continues unchecked, it means the threat to human life and the natural ecology will continue to grow.

\section{The Problem}

Global climate change and economic vulnerabilities especially in the global south have increased the threats to access to clean water for domestic use at the household level. The discourse on the gendered dimensions and access to water by women continues to develop. This study focused on women's access to water in hazardous mining environments in two districts of Mashonaland Central Zimbabwe. Maturure (2008) found out that "over 600000 people are directly involved in illegal panning activities across Zimbabwe's major rivers that include Mazowe, Angwa, Muzvezve, Insiza and Bubi." Illegal and unethical mining practices continue to haunt the country and continue to worsen the plight of the communities in which they operate in. this is in spite of a well-structured legal and institutional framework governing mining in Zimbabwe.

The Environmental Management Act of 2003 Chapter 20:27 clearly states the importance of preserving the environment for the good of the present and future generations. Some very relevant provisions are listed below:

i) Every person shall have a right to protect the environment for the benefit of present and future generations and to participate in the implementation of the promulgation of reasonable legislative policy and other measures that-

ii) Secure ecological sustainable management and use of natural resources whilst promoting justifiable economic and social development.

In spite of this and many other various provisions, the environment has remained under siege from illegal mining activities in most parts of Zimbabwe. The effects of these activities must be analysed using gender lenses to establish how the siege on the environment has affected women and men alike.

The study sought to answer the following objectives; explore the sources of water pollution in Shamva and Bindura Districts in Mashonaland Central Province, to examine how illegal mining activities in the area are affecting women access to clean water and to assess the coping mechanisms employed by women in light of the hazardous environments in which they live in.

\section{A Methodological Prima}


The study was interested in the narratives of women living in hazardous mining environments and was thus interested in establishing the coping mechanisms employed by women in accessing domestic water in their homes. The study was framed in the context of qualitative methodologies and used a case study of two selected districts in Mashonalannd Central Province in Zimbabwe.

Wellington,et al. (2005:97) defined methodology as:

The theory of acquiring knowledge and the activity of considering, reflecting upon and justifying the best methods. Methods are the specific techniques for obtaining the data that will provide the evidence base for the construction of that knowledge.

As noted by Patton (2002:39): "qualitative research methodology uses a naturalistic approach that seeks to understand phenomena in context-specific settings, where the researcher does not attempt to manipulate the phenomenon of interest." The qualitative methodology was used because of its effectiveness when trying to unpack the dynamics that influence human behaviour and perceptions in their social settings, Davies (2007:136).

O'Leary (2010: 113-114) argues that qualitative tradition is in short a critique of positivism as the reigning epistemology and a realisation of the need for alternative ways of producing knowledge. Qualitative methodologies appreciate multiple perspectives and realities as well as subjectivities. More importantly, it values depth as opposed to quantity and 'works at delving into social complexities in order to truly explore and understand the interactions, processes, lived experiences, and belief systems that are a part of • individuals, institutions, cultural groups, and even the everyday.

O'Leary (2010:114) further observes that qualitative methodologies means:

Working in a world that accepts and even values: the • search for holistic meaning; research conducted in natural settings; emergent methodological design; small numbers; non-random sampling strategies; rich qualitative data; inductive analysis; idiographic interpretation; and even the possibility of negotiated outcomes that recognise the need for the researched to be party to a researcher's constructed meanings.

\section{Population and Sample}

The study covered the two districts of Shamva and Bindura Districts in Mashonaland Central. The areas of interest were those that are generally affected by illegal mining. Using a combination of convenient sampling and random sampling, the study participants totalled 49 . There were 4 key informants, 2 from the Environmental Management Agency, and 2 from the Ministry of Mines. The other 40 participants were engaged through random sampling.

Data were collected using interviews and Focus Group Discussions (FDGs). The analysis followed a general inductive approach. As noted by Thomas (2006:38), the primary purpose of the inductive approach is to allow research findings to emerge from the frequent, dominant, or significant themes inherent in raw data, without the restraints imposed by structured methodologies.' Strauss and Corbin (1998) described data analysis as the interplay between researchers and data. Anderson (2010:1) notes that qualitative data analysis is more interested in the meanings attached to the words, actions and feelings as expressed by participants. The meanings are attached to the real world in which the participants live and are linked to existential realities. I used themes and codes to analyse the data and to capture the emerging issues. As noted by Taylor and Gibbs (2010), coding the data makes it easier to search the data, to make comparisons and to identify any patterns that require further investigation.

Thomas (2006:238) identifies three important features of inductive analysis approach:

To condense extensive and varied raw text data into a brief, summary format;

- To establish clear links between the research objectives and the summary findings derived from the raw data and to ensure that these links are both transparent (able to be demonstrated to others) and defensible (justifiable given the objectives of the research); and

To develop a model or theory about the underlying structure of experiences or processes that is evident in the text data.

The data that I collected was processed without the assistance of any computer packages. I relied on two basic approaches, that is, the interpretive analysis and discourse analysis.

\section{Summary of Participants and Sampling and Data Collection Techniques}

\begin{tabular}{|l|l|l|l|}
\hline CATEGORY & SAMPLING TECHNIQUE & SAMPLE & $\begin{array}{l}\text { DATA COLLECTION INSTRUMENT } \\
\text { USED }\end{array}$ \\
\hline EMA Officials & Convenient Sampling & 2 & Interviews \\
\hline $\begin{array}{l}\text { Villagers in } \\
\text { Shamva and } \\
\text { Bindura }\end{array}$ & $\begin{array}{l}\text { Random Sampling from those } \\
\text { that are in areas affected by } \\
\text { mining. }\end{array}$ & 40 & FDGs \\
\hline $\begin{array}{l}\text { Ministry of } \\
\text { Mines }\end{array}$ & Convenient Sampling & 2 & Semi-Structured Interviews \\
\hline $\begin{array}{l}\text { Traditional } \\
\text { Leaders }\end{array}$ & Convenient Sampling & 5 & Interviews \\
\hline
\end{tabular}

Presentation and analysis: Women Coping
Mechanisms

Given the well document poor mining practices, both by the informal and formal miners, the damage on the environment has to be looked at with gendered eyes. 
The pattern of responses in Shamva district in communities around Madziva Mine is characterized by four main approaches

- Differentiation of domestic use of water from different sources

- $\quad$ Travelling Long Distance to secure safe drinking water

- $\quad$ Buying from shops (drinking and cooking)

- Water Harvesting

Differentiation of Domestic use of Water from Different Sources.

The most common response to contaminated water in and around the area has seen families and communities resorting to differentiated use. Families use the contaminated water to do laundry and other cleaning responsibilities. They then either acquire clean and safe water from other sources for drinking and cooking. However, villagers complained that this was not a sustainable solution as quite often they find it difficult to get adequate water for the preparation of meals.

\section{Travelling Long Distances}

This is perhaps the common response as most of the villagers cannot afford to buy water from the shops. Villagers pointed out that since the boreholes around the Madziwa community are all contaminated, they have devised ways of drawing water from Mupfurudzi River which is approximately 17 kilometers from their village. The villagers usually mobilise among themselves, especially women and children, to go and fetch their domestic water from the river. Many others will ferry their laundry to the river where they wash and rinse whilst waiting so that the laundry won't be heavy to carry on their way back.

The women who shared their experiences indicated that because of the long distance, they usually use ox-drawn carts or donkey-drawn carts to fetch water in bulk from the river. It is however important to put the word bulk in its appropriate context. The women said on average each woman can have 60-80 litres of water from the river and this constituted bulk delivery in their context. The bulk water for cooking and drinking purposes usually last for three to five days depending on the size of one's family.

\section{Water Harvesting during Rain seasons}

Another of the popular coping mechanisms which has been adopted by women in the community is waterharvesting. The women-participants indicated that rain seasons often provide them with temporary relief as they maximize on the rains to harvest as much water as they possibly can for domestic use. The participants say they collect water in drums, plastic and metal containers and any other container that can store a lot of water.

The area usually receives fairly average to above average rains each year.However, the participants also revealed that the storage capacity in many households for the rain water is very low. Many of the families cannot store more than 400 litres of water and it is the responsibility of women to ensure that the little that has been harvested will serve the family for as many days as is possible.

\section{DISCUSSION AND ANALYSIS OF THE FINDINGS}

The water situation is Zimbabwe is emerging as a serious security threat. Human security encompasses so many aspects of security including the environment.The largely unregulated and yet tolerated illegal mining activities in Zimbabwe pose a big threat to the country's water bodies. The threats range from siltation, land degradation and more crucially pollution and contamination of water and thus making it difficult with each passing day for communities to access good quality water.Most rural communities in Zimbabwe do not have protected water sources. They rely on the natural water bodies like dams, wells and rivers and in other cases rely on man-made water bodies like boreholes and weirs. Water in the rural communities is largely for domestic use as there are hardly any commercial activities that take place rural environments in Zimbabwe. As a result, access to clean water must be viewed in the context of domestic and gendered roles in these mining communities.

\section{Gendered roles and water use in Zimbabwe}

The role of women is largely differentiated from the role of men especially in the rural set up. During this study, the situation was largely similar to any other prevailing situation in rural Zimbabwe. Women and young girls are largely responsible for household chores that include cooking, fetching water, cleaning the home and doing laundry. Therefore, any challenges to the water situation in a given area impacts more on women than it affects their male counterparts. Men are expected to do the purportedly masculine responsibilities that include clearing the land and perhaps herding livestock. However, the differentiation of duties is skewed in favor of men as they are not over-burdened by responsibilities. The study noted that most women do double the responsibilities as compared to their malecounterparts. On top of the 'traditional' household chores, women also actively partake in fetching firewood, preparing land for planting, tilting and harvesting.

The numerous responsibilitiesput strain on most women. This is then further compounded by the added responsibility of trying to secure clean water for domestic use as some of the sources are getting contaminated through mining activities. The long distance that the women have to travel to identify and fetch clean water means that the time to rest (for the women) is reduced, considering the fact that they also have other important duties at home and in the fields. Therefore, this constrained access to clean water for domestic use must be understood in the context of gendered roles and how it puts an extra strain on women, especially in the rural and mining set ups. The situation is further compounded by unfavorable trends in climate change in the sub-Saharan region.

The coping strategies by these women is labor-intensive and in the long run not very sustainable. There is no guarantee that the remaining few sources of clean water will remain safe from the illegal mining activities that have become a common occurrence in most places across the country as the ordinary citizen struggles to keep up with the economic challenges. The gradual 
change in climate patterns must also be understood in the context of women vulnerabilities. At the domestic level and in the context of this study, it has been demonstrated that women bore the brunt of poor mining and environmental practices as they now employ coping mechanisms that will require them to work double the effort for them to access clean water for domestic use.

\section{Poverty, Women and the Environment}

One of the greatest dilemma in discussing women and access to water is the manner in which they have (over the years) become active participants in the destruction and pollution of the water bodies in their communities. The study realized that a very significant number of the illegal gold panners are women. However, the women easily confessed that they were very much aware of the negative effects of the mining activities that they engage in but were quick to point out that they had no choice as they needed to survive and to provide for their families. The economic challenges that the country continues to experience is a serious driver of environmental destruction as people struggle to make ends meet.

This in turn creates a vicious cycle of poverty, degradation and vulnerability. Poverty is driving communities to engage in activities that destroy the environment and yet inadvertently increasing their vulnerability again. The effects of this can be differentiated as women will have to shoulder the extra burden always. Poverty has seen more and more people turning to the environment for survival in Zimbabwe. The activities that the people do are largely varied but all the same destructive. Others make a living out of deforestation as they cut down trees for firewood, others through illegal mining and illegal fishing activities all of which destroy the environment and pollute water bodies in the process.

\section{Politics, Policing and Illegal Mining in Zimbabwe}

Another issue worth discussing is the relationship between politics and illegal mining in Zimbabwe. The problem of illegal mining and water pollution is much bigger than what meets the eye. The illegal miners conceded that most of the panners commonly known as 'syndicates' enjoy political protection as well as police protection and thus making them immune to protection. Others even claimed that the syndicates pay for their protection and in most cases sell the gold to the politicians. Corruption in the mining sector, especially at the level of artisanal mining, is a huge driver of environmental degradation and water pollution.

This is further compounded by the weak policy enforcement mechanisms by the responsible Ministry and Agency (Environmental Management Agency). Transparency International Zimbabwe (2012) found out that the Zimbabwe Republic Police Minerals Unit, which is the enforcing arm of the mining policies in Zimbabwe often receives bribes and thus weakening their ability to effectively enforce the laws. The research further noted that the ZRP officers usually collude with the illegal miners "to facilitate the deals in gold which is unlawful and proscribed by the law." Whilst this has a negative effect on the country's revenue, the major point of discussion in the context of this study is on how police corruption and laxity in enforcement of both environmental laws and mining laws has contributed to environmental degradation in general and water pollution in particular.

Corruption tends to have disproportionate effects on various constituencies in society. Transparency International (2012) observed that corruption "has a disproportionate impact on people that belong to groups that are exposed to particular risks, such as rural communities which are characterized by poverty and the highest number of poor people." This disproportionate effect must also employ a gender lenses in order to put into perspective how corruption as a practice creates threats to human survival in general and to women in more particular terms.

The indiscriminate use of dangerous chemicals like mercury and cyanide has also been attributed to the weak monitoring frameworks that are available for the supervision of mining in Zimbabwe. The problems are further compounded by the corrupt tendencies among the law-enforcing agencies.

\section{Conclusion and Recommendations}

The study focused on the dynamics of mining in Zimbabwe especially on the illegal mining in two districts in Mashonaland Central and how these activities are contaminating the environment especially access to clean water and the environment by the communities in general but more specifically how it affects women in these communities. The study revealed that mining in Zimbabwe, albeit with a largely well-articulated legal and institutional framework, is largely poorly regulated owing to a raft of reasons. Key explanations as to why the mining activities in the country are poorly regulated have been attributed to political grandstanding and populist (appeasement) policies by the elite politicians as they seek to maintain political poor and would approve mining activities that have a negative effect on the environment in general and water bodies in particular. Many gold partners (now preferred as artisanal miners) are operating without the necessary technology and let alone due diligence to environmental impact assessment of their mining activities. The economic challenges that the country is going though also make it very difficult for the law enforcing agencies to effectively impose the provisions of the law as these miners have nowhere to run to.

In some instances, it was also noted that big cooperate companies were not observing the necessary safety health and environmental due processes for the due discharge of waste from their mining activities and thus polluting the environment and the water around the areas in which they operate.

It was also observed that women constitute a significant number of illegal miners in Mazowe, Bindura and Shamva Districts. The major driving factor being economic survival. The illegal mining activities are actually contributing to the cycle of vulnerability among women as they now carry a dual role of leading the line in poverty alleviation as well as the mainstay at the household level with the whole family looking upon them to provide a meal every day. The research therefore recommends the following:

- The problem of water contamination and environmental degradation has proved to be a complex and deeply entrenched problem in Zimbabwe. A 
combination of poverty-induced threats, corruption and general ignorance have all contributed to the sorry state in which we find our environment in. The solution thus lies in a multi-stakeholder approach in dealing with the problem. There is need to arrest the culture of political impunity as well as corruption within some government agencies like the police and EMA so as to ensure sustainability and effectiveness of the policy framework that is in place.

- $\quad$ There is also need to create awareness among the communities. Although the illegal gold mining trade is said to be controlled by the powerful politicians in Zimbabwe and possibly beyond, the activities can still be rationalized and done in a more environmentally sustainable manner. The government has of late made efforts to promote artisanal mining but this call has not translated into tangible action. Therefore, the government must move with speed to improve the operations within the informal mining sector.

- $\quad$ Corruption is a major factor in the destruction of the environment. It is thus imperative for the authorities to come up with strategies to eliminate corruption in the sector.

\section{REFERENCES}

Anderson, C., 2010 Presenting and Evaluating Qualitative Research https://www.ncbi.nlm.nih.gov/pmc/articles/PMC2 987281 Accessed 28/08/2018

Angula, M., 2010 Gender and Climate Change: Namibia Case Study,Heinrich Böll Foundation Southern Africa, Cape Town.

Aryee, B.N.A., Ntibery, B.K. and Atorkui, E., 2003 "Trends in the Small-scale Mining of precious minerals in Ghana: A perspective on its environmental

impact" www.sciepub.com/reference/4862

Bebe, D. (N.D.) Environmental Damage Caused by Gold Panning in Gwanda District. Masters Dissertation, University of the Free State, Bloemfontein.

Brown, D., Chanakira, R.R., Chatiza, K., Dhliwayo, M., Dodman, D., Masiiwa, M., Muchadenyika, D., Mugabe, P. and Zvigadza, S., 2012 Climate Change Working Paper 3, December 2012. Climate Change Impacts, Vulnerability and Adaptation in Zimbabwe. www.iied.org

Chagutah, T., 2010 Climate Change Vulnerability and Adaptation Preparedness in Southern Africa: Zimbabwe Country Report, Heinrich Böll Stiftung Southern Africa, Cape Town.

Davies, M.B., 2007 Doing a Successful Research Project using Qualitative or Quantitative Methods. London: Palgrave Macmillan

Donkor AK, Bonzongo JC, Nartey VK, Adotey DK (2006) Mercury in different environmental compartments of the Pra River Basin, Ghana. Sci Total Environ 368:164-176
Dreschler, B., 2001 Small-Scale Mining and Sustainable Development within the SADC Region: Mining Minerals and Sustainable Development, Number 84. England: SANTREN/ITDG Environmental Management Act (2003). Government Printers, Harare

Mangwende, S., 2013 Effects of Gold Panning on Communities: A Case Study of Shurugwi District. Masters Dissertation, Midlands State University, Gweru.

Mapira, J.: River pollution in the City of Mutare (Zimbabwe) and Its Implications For Sustainable Development, Journal of Sustainable Development in Africa, 13, 181-194, 2011.

Maturure, M., 2008 Mining Policy Sector Review: A Review of the Legislative and Policy Framework for Community Based Natural Resources Management in the Mining Sector. www.cbrm.campfirezimbabwe.org/index.php?op tion=com contentandview=articleandid=72: $\mathrm{mini}$ ng.policy-sector-review\&catid=36:forum

Mlambo, M., 2013 Zimbabwe's River System Heavily Polluted. The Standard, April 7, 2013

Mpendazoe, F.M.T., 1996 Towards Sustainable Smallscale Gold Mining in Tanzania. Proceedings of the First World Mining Environment, Balkema: Rotterdam.

Mudombi, S. and Muchie, M., 2013 Perceptions of Water Access in the Context of Climate Change by Rural Households in the Seke and Murehwa Districts, Zimbabwe. Jamba: Journal of Disaster Risk Studies (1), Art pp 71-79.

Mujere, N. and Isidro, M., 2016 Impacts of Artisanal and Small-Scale Gold Mining on Water Quality in Mozambique and Zimbabwe, DOI: 10.4018/9781-4666-9559-7.ch005

Nyamukondiwa, P., 2017 Miners Expose Children to Mercury. The Herald, 13 March 2017. www.herald.co.zw/miners-expose-children-tomercuryl

O'Leary, Z., 2010 The Essential Guide to Doing Your Research Project. London: SAGE Publications.

Ongoro, E.B. and Ogara, W., 2012 'Impact of climate change and gender roles in community adaptation: A case study of pastoralists in Samburu East District, Kenya', International Journal of Biodiversity and Conservation 4(2), 78-89.

Oxfam Australia 2009 Women Communities and Mining: The Gender Impacts of Mining and Role of Gender Impact Assessment. Oxford Australia. 
Patton, M.Q., 2002 Qualitative Research and Evaluation Methods $\left(3^{\text {rd }} \mathrm{Ed}\right)$. Thousand Oaks: CA: Sage Publishers.

Prasetyo, B., Krisnayanti, B. D., Utomo, W. H., and Anderson, C. W. N., 2010. Rehabilitation of artisanal mining gold land in West Lombok, Indonesia: 2. Arbuscular mycorrhiza status of tailings and surrounding soils. Journal of Agricultural Science, 2(2), 202-209.

Ross, M.L., 2001 Extractive Sectors and the Poor. Oxfam America: Washington D.C.

Ross, M.L., 1999 The Political Economy of the Resource Curse. World Politics Vol 51(2) pp 297-322.

Schirch, L., 2013 Conflict Assessment and Peacebuilding Planning: A Strategic, Participatory, Systems-Based Handbook on Human Security, Boulder and London: Kumarian Press.

Shoko, D.S.M., 2005 "Small-scale mining and alluvial gold panning within the Zambezi Basin".ParqueNacionaldaGorongosa. http://files. gorongosa.net/filestore/366shokod290502.pdf
Strauss, A. and Corbin, J., 1998 Basics of Qualitative Research, Techniques and Procedures for Developing Grounded Theory, 2nd edition. Thousand Oaks, CA: Sage Publications.

Thomas, D.R., 2006 A General Inductive Approach for Analysing Qualitative Evaluation Data. American Journal of Evaluation, 27 (2):237-246.

Transparency International Zimbabwe 2012 Report on Corruption in the Mining Sector in Zimbabwe.

United Nations DevelopmentProgramme (UNDP), 2010 Gender, climate change and community-based adaptation, United Nations Development Programme, New York.

United Nations Development Programme 1994 Human Development Report.

Wellington, J., Bathmaker, A., Hunt, C., McCulloch, G. and Sikes, P., 2005 Succeeding with Your Doctorate, London: SAGE Publications.

World Health Organization (WHO), 2011 Gender, climate change and health, World Health Organization, viewed 10 May 2013, from http://www.who.int/globalchange/publications/re ports/gender climate change/en/"> 